\title{
Ruptured hepatoblastoma: A case report and literature review
}

\author{
Francesco Saettini ${ }^{1}$, Valentino Conter ${ }^{1}$, Liviana Da Dalt ${ }^{2}$, Giorgio Perilongo ${ }^{2}$, Daisuke Hasegawa ${ }^{3}$, \\ Eugenia Giraldi ${ }^{4}$, Laura Cavalleri ${ }^{4}$, Carlo Foglia ${ }^{4}$, Lorenzo D'Antiga ${ }^{4}$, Massimo Provenzi ${ }^{4}$ \\ 1. Department of Pediatrics, University of Milano-Bicocca, San Gerardo Hospital, Monza, Italy. 2. Department of Woman's \\ and Child's Health, University Hospital of Padua, Padua, Italy. 3. Department of Pediatrics, St. Luke's International \\ Hospital, Tokyo, Japan. 4. Department of Pediatrics, Ospedale Papa Giovanni XXIII, Bergamo, Italy.
}

Correspondence: Francesco Saettini. Address: Department of Pediatrics, San Gerardo Hospital, University of MilanoBicocca, Monza, Italy. Email: francescosaettini@yahoo.it

Received: J une 13, 2013

DOI : $10.5430 /$ jst.v3n5p46
Accepted: October 8, 2013

URL: http://dx.doi.org/10.5430/jst.v3n5p46

Online Published: October 10, 2013

\section{Abstract}

The spontaneous rupture of hepatoblastoma in childhood is a rare life-threatening event. Despite never being firmly documented this event is considered to play a negative impact on long term survival. Herewith the clinical history of a 6-month-old child with a very large mass and intratumoral bleeding at the diagnosis, who suffered of spontaneous tumor rupture after two cycles of pre-operative chemotherapy and ultimately died of tumor recurrence despite appropriate treatment, is reported. In addition to this case the pertinent literature regarding the prognostic implication of tumor rupture in childhood hepatoblastoma (at the time of diagnosis or during treatment) is reviewed. This report is meant to focus the problem of the clinical and prognostic relevance of tumor rupture and to stimulate appropriate large scale studies aimed to investigate the prognostic value of this event, and to identify the clinical tumor characteristics which may predict its occurrence.

\section{Key words}

Hepatoblastoma, Rupture, Solid tumors, Rare tumors, Surgical treatment

\section{Introduction}

The spontaneous rupture of hepatoblastoma (HB), the most common primary malignant liver tumor in children ${ }^{[1,2]}$, is a well-known life-threatening phenomenon, possibly triggered by discordance between tumor growth and neoplastic neo-vascularization. Ruptured HB usually presents with abdominal swelling and acute abdomen ${ }^{[3-17]}$. In these emergency situations, control of hemorrhage, which is life-saving, can be achieved by transcutaneous arterial embolization (TAE) and/or surgical resection. The spontaneous rupture of $\mathrm{HB}$, as for other intra-cavitary tumors, may expose the patient to the risk of intra-abdominal tumor seeding, thus precluding curative resection. So far however definite evidence of the negative prognostic factor of tumor spillage on long term survival of children affected by HB has never been produced.

We herein describe the case of a 6 month-old boy affected by HB who survived a spontaneous rupture after two cycles of pre-operative chemotherapy but subsequently died of tumor recurrence despite appropriate treatment. The pertinent literature regarding the prognostic implication of tumor rupture in childhood hepatoblastoma (at the time of diagnosis or 
during treatment) is also reviewed. This report is meant to focus the problem of the clinical and prognostic relevance of tumor rupture and to stimulate appropriate large scale studies aimed to investigate the prognostic value of this event, and to identify the clinical elements which may predict its occurrence.

\section{Case report}

A six-months old boy was referred to our center because of fever, anemia (hemoglobin $6 \mathrm{~g} / \mathrm{dL}$ ) and an asymptomatic abdominal mass. On arrival his clinical conditions were stable. At the time of diagnosis, the alpha fetoprotein (AFP) level was $2,317 \mathrm{ng} / \mathrm{mL}$ (normal value $<10 \mathrm{ng} / \mathrm{mL}$ ), hemoglobin $5.2 \mathrm{~g} / \mathrm{dL}$ and hematocrit $17.9 \%$. Abdominal ultrasonography (US) confirmed the hepatic origin of the abdominal mass, which was associated with a hemorrhagic lesion of $6 \mathrm{~cm}$ diameter under the glissonian sheath and a modest effusion in the Morrison's pouch. Abdominal computed tomography (CT) revealed an involvement by the tumor of three sections of the liver (segments IVb, V, VI, VII and VIII) and confirmed the presence of a modest peritoneal effusion (Figure 1). The liver mass was mainly hypodense with necrotic areas. No active bleeding was reported. The tumor was classified as PRETEXT III (tumor volume: $10 \mathrm{~cm} \times 9 \mathrm{~cm} \times 7 \mathrm{~cm}$ ) ${ }^{[18]}$. Liver biopsy was in favor of an epithelial HB with predominant fetal component.

After obtaining parental informed consent, the patient was treated according to SIOPEL 3 SR protocol with two cycles of cisplatinum on day 1 and $14^{[1]}$. The AFP decreased to $670 \mathrm{ng} / \mathrm{mL}$ after the first cycle of pre-operative chemotherapy. Six days after the second cycle of cisplatinum the patient presented an increased, distended abdominal girth, fever and elevated C-reactive protein. AFP level was $415 \mathrm{ng} / \mathrm{mL}$. US and CT showed an increase in liver size, abdominal effusion and active bleeding from an intrahepatic vessel (Figure 2). Hemoglobin and platelet count decreased to $4.5 \mathrm{~g} / \mathrm{dL}$ and $26.000 / \mathrm{mcl}$ respectively (with no evidence of coagulation abnormalities). The clinical picture was thus suggestive of a spontaneous tumor rupture. It was decided to perform TAE, which allowed to confirm the diagnosis, and to control bleeding with an improvement of patient's clinical condition. After this procedure, surgical hemostasis and peritoneal cavity lavage were performed. No tumor cells were found in the ascitic fluid. One week later the patient underwent partial hepatectomy. Since microscopic margins were not clear it was decided to administer an intensified post-operative chemotherapy regimen (cisplatinum and doxorubicin) ${ }^{[2]}$.

One month after stopping therapy the patient presented with dyspnea. CT showed multiple extra-hepatic (intra-abdominal) and lung metastases. Rescue chemotherapy was administered with no response and the patient died of progressive disease one month after recurrence.

Figure 1. Pre-operative abdominal computed tomography scan showing necrotic areas (stars) and free fluid (arrow).

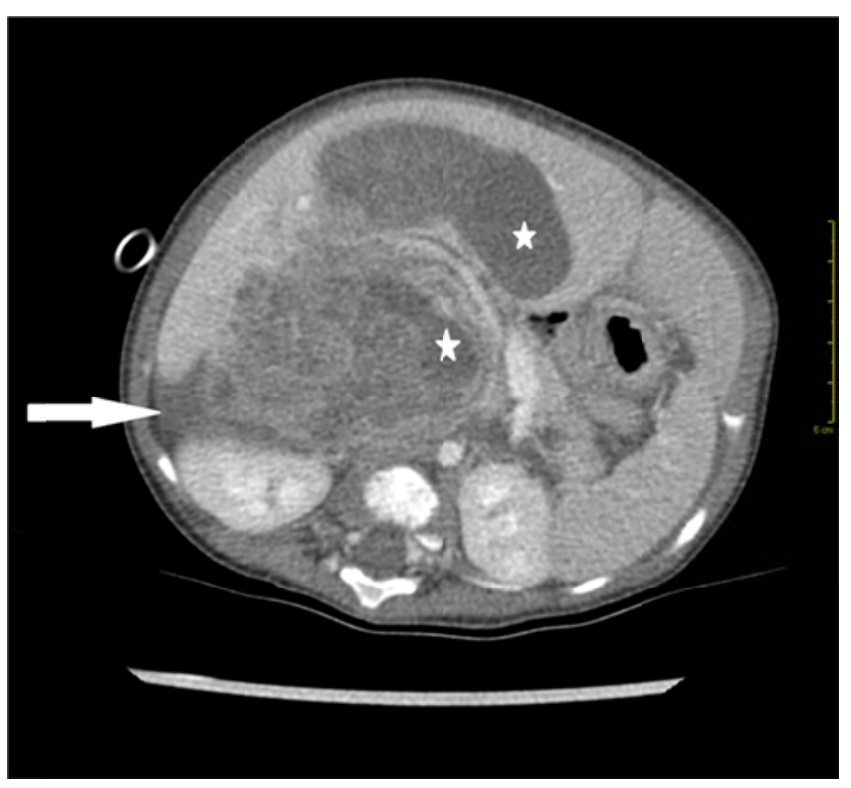


Figure 2. Computed tomography scan at the time of the rupture showing a ruptured intrahepatic vessel (arrow) and free fluid (star)

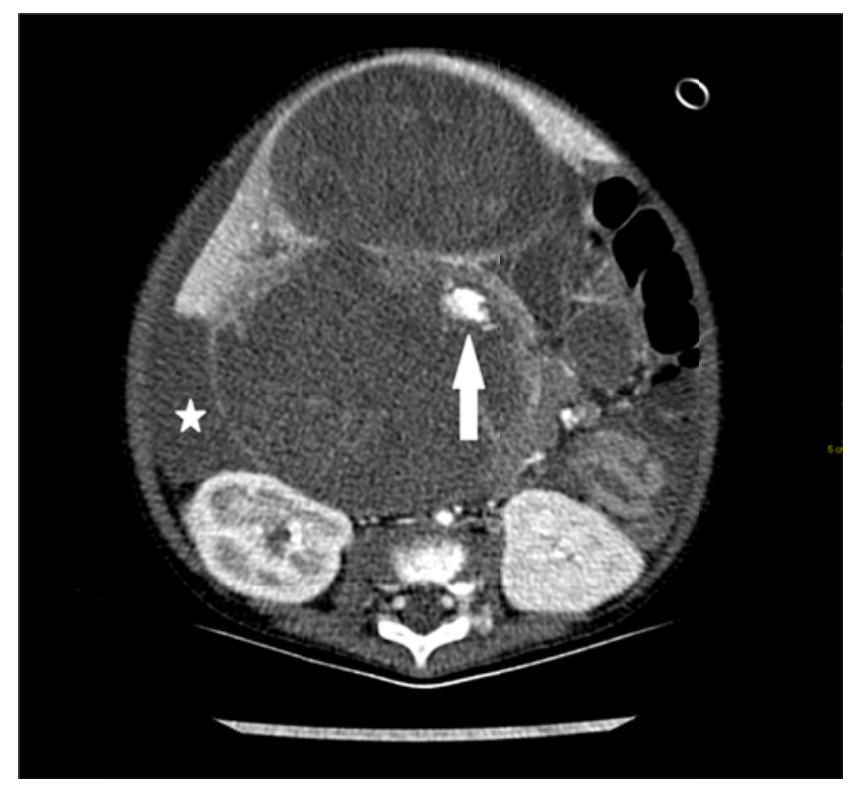

\section{Discussion}

According to the different series reported, the frequency of spontaneous tumor rupture, which does not include localized, subcapsular hemorrhage as well as biopsy-related intra-peritoneal bleeding, occurs in 2.9 to $8.6 \%$ of patients affected by $\mathrm{HB}^{[19-21]}$. This rare event must be regarded as a life-threating condition because of the potential massive intra-abdominal bleeding which can be associated with the tumor rupture. The diagnosis is usually suspected on the basis of clinical and laboratory findings (i.e. hypotension and low hematocrit or hemoglobin level) and confirmed by diagnostic imaging. Tumor size and general condition of the patient are important factors while considering treatment options. Although TAE is successful in achieving hemostasis in adult patients, it is a technically difficult procedure in infants. On the other hand, emergency resections in ruptured liver tumors are associated with high mortality ${ }^{[6]}$ because massive blood loss and shock may result in significant ischemic injury to the liver and major resection would result in very little residual liver function. Presently the International Childhood Liver Tumor Study Group - SIOPEL - considers tumor rupture as a negative prognostic factor, based on the assumption that the tumor bleeding can cause tumor cell seeding within the abdominal cavity, thus making more difficult the complete eradication of the neoplasm and favoring hematologic tumor dissemination. However solid data in supporting this hypothesis have never been produced.

The reports describing cases of spontaneous tumor rupture in childhood HB published in the literature have been carefully reviewed in order to try to identify possible predicting factors of this event and to try to understand its possible prognostic implication. We were able to collect 20 cases (including the one here reported) whose relevant clinical findings are described in Table 1.

The spontaneous rupture of $\mathrm{HB}$ has been described at the time of diagnosis in 17 cases and during treatment in 3 patients only, including the one herein described. Patients' median age at diagnosis of HB was 6 months, which appears to be much younger than the median age of the cohorts of children with HB enrolled in the modern large cooperative trials ${ }^{[22]}$. Nine children were males and 8 females. The median maximum tumor diameter was $10 \mathrm{~cm}$. For eleven patients the PRETEXT was available, four had a PRETEXT II neoplasm, four a PRETETX III and three a PRETEXT IV HB ${ }^{[1,2]}$. Blood tests revealed a rapidly progressive decrease of hemoglobin level. Of the 12 cases with information available, 6 were born prematurely (versus $20 \%$ in the general population of patients with $\mathrm{HB}$ ) ${ }^{[23]}$. The patients' outcome has been described in 17 cases; 3 died the same day the bleeding was documented, 1 died of other unrelated causes, and 5 of the remaining 13 died of disease progression; thus only 8 out of 17 were long term survivors. In summary, from this small series of cases of spontaneous HB tumor rupture, it appears that very young children, especially if premature and presenting with a large 
tumor mass should be carefully monitored for the occurrence of this rare event. Likewise, as in the case herein reported, a low hemoglobin level at diagnosis especially if associated with radiological evidence of intratumoral bleeding can herald the catastrophic event of the spontaneous tumor rupture. Finally, outcome data reported in the literature supports the concept of the possible negative prognostic value of tumor rupture.

Table 1. Reported cases of ruptured HB at diagnosis, after diagnosis and during POC

\begin{tabular}{|c|c|c|c|c|c|c|c|c|c|c|c|}
\hline \multirow[b]{2}{*}{ Author } & \multirow[b]{2}{*}{ Year } & \multirow{2}{*}{$\begin{array}{l}\text { No } \\
\text {. of } \\
\text { pts }\end{array}$} & \multirow[b]{2}{*}{ Premature } & \multirow{2}{*}{$\begin{array}{l}\text { Age } \\
\text { ISex }\end{array}$} & \multicolumn{4}{|c|}{ Diagnosis } & \multicolumn{2}{|c|}{ Rupture } & \multirow[b]{2}{*}{ Survival } \\
\hline & & & & & $\begin{array}{l}\text { Tumor } \\
\text { size }\end{array}$ & $\begin{array}{l}\text { Clinical } \\
\text { features }\end{array}$ & Histology & $\begin{array}{l}\text { Radiological } \\
\text { features }\end{array}$ & $\begin{array}{l}\text { Time } \\
\text { from } \\
\text { diagnosis }\end{array}$ & Lobe & \\
\hline $\begin{array}{l}\text { Hsu } \\
\text { et al. }{ }^{[3]}\end{array}$ & 1984 & 1 & - & $10 \mathrm{~m} / \mathrm{M}$ & - & $\begin{array}{l}\text { Vomiting, } \\
\text { anemia }\end{array}$ & - & - & Dia & & DoD 4 m \\
\hline $\begin{array}{l}\text { Van de } \\
\text { Bor et } \\
\text { al. } .^{4]}\end{array}$ & 1985 & 1 & $29 w$ & $\begin{array}{l}\text { Newborn } \\
\text { /M }\end{array}$ & $7 \mathrm{~cm}$ & Shock & Fetal & - & Dia & & $\begin{array}{l}\text { Died the } \\
\text { same day }\end{array}$ \\
\hline $\begin{array}{l}\text { Kitahara } \\
\text { et al. }{ }^{[5]}\end{array}$ & 1995 & 1 & - & $16 \mathrm{~m} / \mathrm{F}$ & $\begin{array}{l}\text { Pretext IV, } \\
10 \mathrm{~cm}\end{array}$ & $\begin{array}{l}\text { Vomiting, liver } \\
\text { dysfunction, } \\
\text { Hb } 7.5 \mathrm{~g} / \mathrm{dL}\end{array}$ & $\begin{array}{l}\text { Mixed } \\
\text { mesenchymal }\end{array}$ & $\begin{array}{l}\text { Heterogeneous } \\
\text { and multifocal }\end{array}$ & 1d after Dia & L & $\begin{array}{l}\text { Died of } \\
\text { Reye S. } \\
30 \mathrm{~m} \text { after }\end{array}$ \\
\hline $\begin{array}{l}\text { Hojo } \\
\text { et al. }{ }^{[6]}\end{array}$ & 1996 & 1 & $34 w, 2300 g$ & $1 \mathrm{~m} / \mathrm{M}$ & $6 \mathrm{~cm} \times 8 \mathrm{~cm}$ & $\begin{array}{l}\text { Hemorrhagic } \\
\text { shock }\end{array}$ & $\begin{array}{l}\text { Poorly } \\
\text { differentiated }\end{array}$ & - & Dia & $\mathrm{L}$ & DoD \\
\hline $\begin{array}{l}\text { Chan } \\
\text { et al. }{ }^{[7]}\end{array}$ & 1998 & 1 & No & $6 \mathrm{~m} / \mathrm{F}$ & $\begin{array}{l}\text { Pretext III, } \\
15 \mathrm{~cm} \times 10 \mathrm{c} \\
\mathrm{m} \times 12 \mathrm{~cm}\end{array}$ & Stable & - & $\begin{array}{l}\text { Stretched right } \\
\text { hepatic artery } \\
\text { with multiple } \\
\text { minor tumor } \\
\text { vessels }\end{array}$ & $2 \mathrm{~d}$ after dia & $\mathrm{R}$ & $\begin{array}{l}\mathrm{NED} \\
\text { at } 4 \mathrm{~m}\end{array}$ \\
\hline $\begin{array}{l}\text { Lee } \\
\text { et al. }{ }^{[8]}\end{array}$ & 1999 & 1 & No & $\begin{array}{l}\text { Newborn } \\
\text { /F }\end{array}$ & Pretext II & $\mathrm{Hb} 7.6$ & - & - & Dia & L & $\begin{array}{l}\text { NED } \\
\text { at } 13 \mathrm{~m}\end{array}$ \\
\hline $\begin{array}{l}\text { Nagata T } \\
\text { el al. }{ }^{[9]}\end{array}$ & 1999 & 1 & - & $4 y / F$ & Stage IV & $\begin{array}{l}\text { Anemia, liver } \\
\text { dysfunction }\end{array}$ & $\begin{array}{l}\text { Highly } \\
\text { differentiated }\end{array}$ & - & $\begin{array}{l}12 \mathrm{~d} \text { after } \\
\text { first cycle } \\
\text { of POC }\end{array}$ & $R+L$ & DoD \\
\hline \multirow[t]{3}{*}{$\begin{array}{l}\text { Chan } \\
\text { et al. }{ }^{[10]}\end{array}$} & 2002 & 3 & Yes & $6 \mathrm{~m} / \mathrm{F}$ & $2 \mathrm{~cm}$ & $\begin{array}{l}\text { Shock, Hb } 6.1 \\
\text { g/dL, BP } \\
87 / 63 \mathrm{mmHg}\end{array}$ & - & - & Dia & - & $\begin{array}{l}\text { Died the } \\
\text { same day }\end{array}$ \\
\hline & & & No & $16 \mathrm{~m} / \mathrm{M}$ & Pretext III & Unstable & - & - & Dia & $\mathrm{R}$ & $\begin{array}{l}\text { NED } \\
\text { at } 24 \mathrm{~m}\end{array}$ \\
\hline & & & No & $5 \mathrm{~m} / \mathrm{F}$ & $12 \mathrm{~cm}$ & $\mathrm{Hb} 8.4$ & - & - & Dia & $\mathrm{R}$ & $\begin{array}{l}\text { NED } \\
\text { at } 24 \mathrm{~m}\end{array}$ \\
\hline $\begin{array}{l}\text { Oue et } \\
\text { al. }{ }^{[11]}\end{array}$ & 2003 & 1 & $23 w ; 670 g$ & $16 \mathrm{~m} / \mathrm{M}$ & $\begin{array}{l}\text { Pretext IV, } \\
\text { multifocal }\end{array}$ & $\begin{array}{l}\text { Liver } \\
\text { dysfunction }\end{array}$ & $\begin{array}{l}\text { Well } \\
\text { differentiated }\end{array}$ & Multifocal & Dia & - & $\begin{array}{l}\text { DoD at } \\
7 \mathrm{~d}\end{array}$ \\
\hline $\begin{array}{l}\text { lida et } \\
\text { al. }^{[12]}\end{array}$ & 2004 & 1 & No & $12 y / M$ & $\begin{array}{l}\text { Pretext II, } \\
5 \mathrm{~cm} \times 5 \mathrm{~cm}\end{array}$ & $\begin{array}{l}\mathrm{Hb} 6.9 \text {, liver } \\
\text { dysfunction }\end{array}$ & Epithelial & $\begin{array}{l}\text { Subcapsular } \\
\text { hematoma, } \\
\text { right } \\
\text { subphrenic and } \\
\text { perirectal fluid }\end{array}$ & $1 \mathrm{~d}$ after dia & $\mathrm{R}$ & $\begin{array}{l}\text { NED at } \\
25 \mathrm{~m}\end{array}$ \\
\hline $\begin{array}{l}\text { Towu et } \\
\text { al. }{ }^{[13]}\end{array}$ & 2004 & 3 & - & - & - & - & - & pormostur ma & $\begin{array}{l}\text { Dia } \\
\text { Dia } \\
\text { During } \\
\text { surgery }\end{array}$ & - & - \\
\hline $\begin{array}{l}\text { Ueno } \\
\text { et al. }\end{array}$ & 2005 & 1 & - & $2 \mathrm{~m} / \mathrm{F}$ & Pretext II & $\begin{array}{l}\text { Seizures, } \mathrm{Hb} \\
4.7 \mathrm{~g} / \mathrm{dL}\end{array}$ & $\begin{array}{l}\text { Well } \\
\text { differentiated }\end{array}$ & Free fluid & Dia & & NED 4y \\
\hline $\begin{array}{l}\text { Madanur } \\
\text { et al. }{ }^{[15]}\end{array}$ & 2007 & 1 & - & $5 \mathrm{~m} / \mathrm{M}$ & $\begin{array}{l}\text { Pretext III, } \\
12 \mathrm{~cm}\end{array}$ & $\begin{array}{l}\text { Shock, Hb 3, } \\
\text { K } 6 \text { mmol, } \\
\text { Lactate } 12.4 \\
\mathrm{mmol} / \mathrm{L}\end{array}$ & Embryonal & Heterogeneous & Dia & $\mathrm{R}$ & $\begin{array}{l}\text { NED at } \\
6 \mathrm{y}\end{array}$ \\
\hline $\begin{array}{l}\text { Nitta et } \\
\text { al. }{ }^{[16]}\end{array}$ & 2012 & 1 & No & $7 \mathrm{~m} / \mathrm{M}$ & Huge & $\begin{array}{l}\mathrm{CP} \text { arrest, } \mathrm{Hb} \\
8.1\end{array}$ & - & Calcifications & Dia & $\mathrm{R}$ & $\begin{array}{l}\text { Died the } \\
\text { same day }\end{array}$ \\
\hline $\begin{array}{l}\text { Lay } \\
\text { et al. }{ }^{[17]}\end{array}$ & 2012 & 1 & $36 w$ & $\begin{array}{l}\text { Newborn } \\
\text { /F }\end{array}$ & $\begin{array}{l}\text { Pretext II, } \\
6 \mathrm{~cm} \times 5 \mathrm{~cm} \times \\
2 \mathrm{~cm}\end{array}$ & $\begin{array}{l}\text { Ht 26, liver } \\
\text { disfunction }\end{array}$ & Fetal & $\begin{array}{l}\text { Intraperitoneal } \\
\text { blood }\end{array}$ & Dia & $\mathrm{R}$ & $\begin{array}{l}\text { Alive } \\
\text { completing } \\
\text { POC }\end{array}$ \\
\hline $\begin{array}{l}\text { Saettini } \\
\text { et al.** }\end{array}$ & $\begin{array}{l}\text { this } \\
\text { paper }\end{array}$ & 1 & No & $6 \mathrm{~m} / \mathrm{M}$ & $\begin{array}{l}\text { Pretext III, } \\
10 \mathrm{~cm} \times 9 \mathrm{c} \\
\mathrm{m} \times 7 \mathrm{~cm}\end{array}$ & $\begin{array}{l}\text { Hb } 5.2 \mathrm{~g} / \mathrm{dL} \text {, } \\
\text { liver } \\
\text { dysfunction }\end{array}$ & Fetal & $\begin{array}{l}\text { Heterogeneous } \\
\text {, necrotic areas, } \\
\text { subcapsular } \\
\text { hematoma }\end{array}$ & $\begin{array}{l}1 \mathrm{~m} \text { after } \\
\text { Dia }\end{array}$ & $\mathrm{R}$ & DoD at $2 m$ \\
\hline
\end{tabular}

Note. Pts = patients. $-=$ unknown. $\mathrm{m}=$ months. $\mathrm{M}=$ male. Dia $=$ diagnosis. $\mathrm{d}=$ day. $\mathrm{L}=$ left. $\mathrm{DoD}=$ died of disease. $\mathrm{F}=$ female. $\mathrm{R}=$ right. $\mathrm{NED}=$ no evidence of disease. $\mathrm{BP}=$ blood pressure.

$\mathrm{Hb}=$ hemoglobin. $\mathrm{K}=$ potassium. $\mathrm{CP}=$ cardiopulmonary. $\mathrm{Ht}=$ hematocrit. $\mathrm{POC}=$ post-operative chemotherapy. $\mathrm{y}=$ years. $\mathrm{w}=$ weeks. * = The case reported in this paper. “-” means "unknown"

In conclusion, clinicians caring for children with HB must be fully aware of the possibility of a spontaneous tumor rupture, which can be fatal, due to uncontrolled bleeding, or associated with poorer long term outcome, due to an increased risk of tumor recurrence. Thus effective measurements should be always put in place in order to identify the early clinical and radiological evidence of this rare complication and to treat it successfully.

\section{Declaration of interest}

The authors report no conflict of interest. 


\section{References}

[1] Perilongo G, Maibach R, Shafford E, et al. Cisplatin versus Cisplatin plus Doxorubicin for Standard-Risk Hepatoblastoma. N Engl J Med. 2009; 361: 1662-70. PMid:19846851 http://dx.doi.org/10.1056/NEJMoa0810613

[2] Zsiros J, Maibach R, Shafford E, et al. Successful treatment of childhood high-risk hepatoblastoma with dose-intensive multiagent chemotherapy and surgery: Final results of the SIOPEL 3-HR study. J Clin Oncol. 2010; 28: 2584-2590. PMid:20406943 http://dx.doi.org/10.1200/JCO.2009.22.4857

[3] Hsu ET, Stringel G. Spontaneous rupture of hepatoblastoma in an infant. Clin Paediatr. 1984; 23: 646.

[4] van de Bor M, Verwey RA, van Pel R. Acute polyhydramnios associated with fetal hepatoblastoma. Eur J Obstet Gynecol Reprod Biol. 1985; 20(1):65-69. http://dx.doi.org/10.1016/0028-2243(85)90085-1

[5] Kitahara S, Makuuchi M, Ishizone S, et al. Successful left trisegmentectomy for ruptured hepatoblastoma using intraoperative transarterial embolization. J Pediatr Surg. 1995; 30(12):1709-1712. http://dx.doi.org/10.1016/0022-3468(95)90460-3

[6] Hojyo H, Saito A, Wakasa H. Sozanji ni hasseishi fukkunai shukketsu niyori shiboshita Hepatoblastoma no ichire (in Japanese). Jpn J Pediatr Oncol. 1996; 33: 87.

[7] Chan KL, Tam PK. Successful right trisegmentectomy for ruptured hepatoblastoma with preoperative transcatheter arterial embolization. J Pediatr Surg. 1998; 33(5):783-786. http://dx.doi.org/10.1016/S0022-3468(98)90221-4

[8] Lee SC, Chung JW, Kim KH, et al. Successful Transumbilical Embolization of Congenitally Ruptured Hepatoblastoma. J Pediatr Surg. 1999; 34: 1851-1852. http://dx.doi.org/10.1016/S0022-3468(99)90329-9

[9] Nagata T, Mugishima H, Shichino H, et al. Setsujofunokangashu ni taisuru jutsuzenkagakuryoho no igi to mondaiten (in Japanese). Jpn J Pediatr Oncol. 1999; 36: 57-61.

[10] Chan KL, Fan ST, Tam PKH, et al. Management of Spontaneously Ruptured Hepatoblastoma in Infancy. Med Pediatr Oncol. 2002; 38: 137-138. PMid:11813186 http://dx.doi.org/10.1002/mpo.1292

[11] Oue T, Kubota A, Okuyama H, et al. Hepatoblastoma in Children of Extremely Low Birth Weight: A Report From a Single Perinatal Center. J Pediatr Surg. 2003: 38(1): 134-137. PMid:12592636 http://dx.doi.org/10.1053/jpsu.2003.50027

[12] Iida T, Suenaga M, Takeuchi Y et al. Successful Resection of a Ruptured Hepatoblastoma Prior to Chemotherapy: Report of a Case. Surg Today. 2004; 34: 710-714. PMid:15290405 http://dx.doi.org/10.1007/s00595-004-2766-9

[13] Towu E, Kiely E, Pierro A, et al. Outcome and Complications after Resection of Hepatoblastoma. J Pediatr Surg. 2004; 39: 199-202. PMid:14966740 http://dx.doi.org/10.1016/j.jpedsurg.2003.10.013

[14] Ueno S, Hirakawa H, Yokohama S, et al. Treatment of infantile Hepatoblastoma and related complications. Tokai J Exp Med. 2005:30:203-209.

[15] Madanur MA, Battula N, Davenport M, et al. Staged resection for a ruptured hepatoblastoma: a 6-year follow-up. Pediatr Surg Int. 2007; 23: 609-611. PMid:17066271 http://dx.doi.org/10.1007/s00383-006-1827-0

[16] Nitta A, Hisamatsu S, Fukuda H, et al. Cardiopulmonary Arrest on Arrival in an Infant due to Ruptured Hepatoblastoma. J Pediatr. 2012; 160: 351. PMid:21996157 http://dx.doi.org/10.1016/j.jpeds.2011.08.068

[17] Lai M, Burjonrappa S. Perinatal hemorrhage complicating neonatal hepatoblastoma: case report. J Pediatr Surg. 2012; 47(10): 29-32. PMid:23084227 http://dx.doi.org/10.1016/j.jpedsurg.2012.05.030

[18] Aronson DC, Schnater JM, Staalman CR, et al. Predictive value of the pretreatment extent of disease system in hepatoblastoma: results from the International Society of Pediatric Oncology Liver Tumor Study Group SIOPEL-1 study. J Clin Oncol. 2005: 23: 1245-1252. PMid:15718322 http://dx.doi.org/10.1200/JCO.2005.07.145

[19] Kasai M, Watanabe I. Histologic classification of liver-cell carcinoma in infancy and childhood and its clinical evaluation. A study of 70 cases collected in Japan. Cancer. 1970; 25:551-563. http://dx.doi.org/10.1002/1097-0142(197003)25:3<551::AID-CNCR2820250309>3.0.CO;2-5

[20] Ishak KG, Glum PR. Hepatoblastoma and hepatocarcinoma in infancy and childhood. Report of 47 cases. Cancer. 1967; 20(3):396-422. http://dx.doi.org/10.1002/1097-0142(1967)20:3<396::AID-CNCR2820200308>3.0.CO;2-O

[21] Lack EE, Neave C, Vawter GF. Hepatoblastoma: A clinical and pathologic study of 54 cases. Am J Surg Path. 1982(6); 8: 609-705.

[22] Reynolds P, Urayama KY, Von Behren J, et al. Birth Characteristics and Hepatoblastoma Risk in Young Children. Cancer. 2004:100:1070-1076. PMid:14983504 http://dx.doi.org/10.1002/cncr.20061

[23] Maibach R, Roebuck D, Brugieres L, et al. Prognostic stratification for children with hepatoblastoma: The SIOPEL experience Eur J Cancer. 2012: 48: 1543-1549. PMid:22244829 http://dx.doi.org/10.1016/j.ejca.2011.12.011 